\title{
Peningkatan Kemampuan Metakognisi dan Hasil Belajar Siswa dengan Pendekatan Keterampilan Proses Melalui Think Pair Share pada Siswa Kelas X-3 SMAN Yosowilangun Lumajang Tahun 2014/2015 (Improvement of Metacognition Ability and Achievement Result Using Process Skill Approach Through Think Pair Share in Student Class X-3 SMAN Yosowilangun Lumajang Year 2014/2015)
}

\author{
Indri Pratiwi, Suratno, Moch. Iqbal \\ Program Studi Pendidikan Biologi, Fakultas Keguruan dan Ilmu Pendidikan, Universitas Jember \\ Jln. Kalimantan 37, Jember 68121 \\ E-mail: suratno.fkip@unej.ac.id
}

\begin{abstract}
Abstrak
Penelitian ini bertujuan untuk mengetahui peningkatan kemampuan metakognisi dan hasil belajar siswa dalam pembelajaran Biologi menggunakan pendekatan keterampilan proses melalui Think Pair Share pada kelas X-3 SMA Negeri Yosowilangun tahun pelajaran 2014/2015. Bentuk penelitian ini adalah penelitian tindakan kelas (PTK). Rancangan penelitian tindakan kelas berbentuk spiral dari siklus yang satu ke siklus berikutnya. Tahapan satu siklus meliputi: perencanaan (planning), tindakan (action), pengamatan (observation), dan refleksi (reflection). Teknik pengumpulan data menggunakan observasi, wawancara, dokumentasi, tes, dan monitoring. Data yang diperoleh dianalisis dengan deskriptif kuantitatif. Kemampuan metakognisi pra siklus sebesar $37,48 \%$, siklus 1 meningkat menjadi $60,98 \%$, sedangkan siklus 2 meningkat menjadi $74,31 \%$. Rata-rata hasil belajar kognitif pra siklus sebesar 54,50 meningkat di siklus 1 menjadi 66,06, kemudian meningkat lagi pada siklus 2 menjadi sebesar 77,18. Rata-rata hasil belajar afektif pada siklus 1 sebesar 66,24 kemudian meningkat pada siklus 2 menjadi 78,10, sedangkan rata-rata hasil belajar psikomotor pada siklus 1 sebesar 66,10 kemudian meningkat pada siklus 2 menjadi 78,44. Hasil analisis data menunjukkan adanya peningkatan kemampuan metakognisi dan hasil belajar siswa dalam pembelajaran biologi dengan menggunakan pendekatan keterampilan proses melalui Think Pair Share di kelas X-3 SMA Negeri Yosowilangun tahun pelajaran 2014/2015.
\end{abstract}

Kata Kunci: hasil belajar, metakognisi, pendekatan keterampilan proses, think pair share

\section{Abstract}

This study aimed to determine the improvement of ability metacognition and student learning outcomes in learning biology using process skills approach through model Think Pair Share on class X-3 SMA Yosowilangun academic year 2014/2015. This research utilized classroom acion research (PTK) using spiral design from one cycle to the next cycle. The cycle stage includes: planning, action, observations, and reflection. Data collected through observation, interviews, documentation, testing, and monitoring. The metacognition ability to pre-cycle was 37,48\%, cycle 1 increased to $60,98 \%$, while cycle 2 increased to $74,31 \%$. The average cognitve learning result pre-cycle was 54,50 increased in cycle 1 to be 66,06, then increases in cycle 2 to be 77,18. The average affective learnng result in cycle 1 of 66,24 then increased in cycle 2 to be 78,10 , while the average psychomotor learning result cycle 1 of 66,10 then increased in cycle 2 to be 78,44 . Results of this research were analyzed with descriptive quantitative and showed an increased ability metacognition and student learning outcomes in learning biology by using process skills approach through Think Pair Share in class X-3 SMA Yosowilangun academic year 2014/2015.

Keywords: Achievement, metacognition, skill approach process, think pair share

\section{Pendahuluan}

Dunia pendidikan saat ini telah menjadi sorotan utama bagi pemerintah untuk meningkatkan kecerdasan generasi muda. Upaya peningkatan kualitas pendidikan hingga kini terus dilakukan, mulai dari penyempurnaan kurikulum, peningkatan mutu guru, berbagai pelatihan hingga penggadaan fasilitas belajar. Peningkatan mutu guru tidak lain dengan tujuan untuk meningkatkan capaian hasil belajar siswa, salah satunya dengan cara menerapkan pembelajaran inovatif. Pembelajaran inovatif dapat dicapai apabila guru menggunakan model dan metode-metode pembelajaran yang memacu keterampilan siswa, baik dalam hal kognitif, afektif, maupun psikomotor ${ }^{[1]}$.

Biologi merupakan bagian dari Sains yang mempunyai dua dimensi, yaitu dimensi proses dan dimensi produk. Dimensi proses ini sangat terkait dengan kemampuan metakognisi siswa, sedangkan dimensi produk terkait dengan hasil belajar siswa. Kemampuan metakognisi dan prestasi akademik memiliki hubungan positif yang dapat diberdayakan ${ }^{[2]}$. Kenyataan dalam pembelajaran biologi yang dilakukan selama ini semata-mata hanya menekankan pada penguasaan konsep kognitif yang didapatkan dengan tes tulis 
objektif, sedangkan ruang untuk metakognisi kurang diberdayakan. Kegiatan belajar seperti ini membuat siswa cenderung belajar mengingat atau menghafal dan tanpa memahami atau tanpa mengerti apa yang diajarkan oleh gurunya. Akibatnya ketika siswa dihadapkan dengan masalah, siswa mengalami kesulitan untuk memecahkannya.

Berdasarkan hasil wawancara dengan responden guru guru Biologi SMAN Yosowilangun menyebutkan bahwa hasil belajar siswa rendah. Rendahnya hasil belajar ini disebabkan oleh metode yang digunakan guru dalam pembelajaran, yaitu metode ceramah. Pengunanaan metode ceramah mengarah pada penumpukan informasi yang kurang bermanfaat bahkan tidak bermanfaat sama sekali, jika hal tersebut hanya dikomunikasikan guru kepada siswa tanpa melalui pemahaman konsep. Hal ini mengakibatkan siswa sulit memahami materi yang diajarkan, kurang terlatih untuk mengembangkan daya berpikirnya dalam mengembangkan konsep yang telah dipelajari dari kehidupan nyata. Proses pembelajaran seperti ini akan membuat siswa menjadi pasif dalam belajar, siswa cenderung diam, hanya mendengarkan materi yang disampaikan oleh guru, serta hanya sibuk dengan dunianya sendiri, sehingga menyebabkan hasil belajar siswa rendah.

Berdasarkan data yang diperoleh, kelas X-3 memiliki ratarata kelas yang paling rendah diantara kelas lainnya artinya pada kelas tersebut masih cukup banyak hasil belajar siswa yang msih belum mencapai Kriteria Ketuntasan Minimal (KKM) yaitu 73. Dikelas X-3 ketuntasan secara klasikal hanya sebesar $8,82 \%$, sedangkan daya serap klasikal di SMAN Yosowilangun sebesar $80 \%$. Rendahnya hasil belajar siswa juga diduga akibat tidak pernah dilakukan pemberdayaan kemampuan metakognisi siswa oleh guru. Siswa yang memiliki prestasi akademik rendah dapat diperbaiki melalui latihan metakognisi ${ }^{[2]}$. Data hasil observasi menunujukkan bahwa kemampuan siswa di kelas X-3 secara klasikal sebesar 37,48\% dan termasuk ke dalam kriteria beresiko. Upaya yang dapat dilakukan untuk mengatasi masalah ini adalah memberdayakan kemampuan metakognisi siswa agar berdampak pula pada hasil belajar siswa. Prestasi belajar siswa yang memiliki tingkat metakognisi tinggi akan lebih baik jika dibandingkan dengan siswa yang memiliki tingkat metakognisi rendah.

Kemampuan metakognisi anak tidak muncul dengan sendirinya, tetapi memerlukan latihan sehingga menjadi kebiasaan. Berdasarkan pernyataan tersebut maka diperlukan pengolahan proses pembelajaran yang tepat. Salah satu caranya yakni mengajak siswa berinteraksi secara langsung dengan sumber belajar yang digunakan sehingga dengan adanya aktivitas ini maka siswa dilatih untuk mengembangkan kemampuan metakognisinya dalam kegiatan pembelajaran. Pendekatan pembelajaran yang dapat mengembangkan keterampilan dan sikap yang dimiliki siswa, salah satunya yaitu pendekatan keterampilan proses. Menurut Dimyati dan Mudjiono dalam Rahayu, menyatakan bahwa pendekatan keterampilan proses sebagai wawasan atau anutan pengembangan keterampilan-keterampilan intelektual, sosial, dan fisik yang bersumber dari kemampuan-kemampuan mendasar yang pada prinsipnya telah ada dalam diri pebelajar.
Adapun model pembelajaran yang sebaiknya menekankan, menggambarkan kemampuan berfikir siswa, bertukar pikiran dengan temannya, dan kemampuan metakognisi siswa salah satunya adalah Think Pair Share (TPS). Think Pair Share adalah jenis pembelajaran kooperatif yang mempengaruhi pola interaksi siswa ${ }^{[3]}$. Model TPS memberikan kesempatan kepada siswa untuk lebih banyak berfikir, merespon, dan saling membantu sehingga model ini dapat digunakan untuk meningkatkan hasil belajar serta kesadaran siswa akan kemampuan pada dirinya sendiri. Berdasarkan paparan di atas maka tujuan penelitian ini adalah untuk mengetahui peningkatan kemampuan metakognisi dan hasil belajar siswa dalam pembelajaran biologi menggunakan pendekatan keterampilan proses melalui think pair share (TPS) pada siswa kelas X-3 SMAN Yosowilangun tahun pelajaran 2014/2015.

\section{Metode Penelitian}

Penelitian ini merupakan penelitian tindakan kelas (PTK) yaitu dengan menerapkan pendekatan keterampilan proses melalui think pair share (TPS) pada siswa kelas X-3 SMAN Yosowilangun tahun pelajaran 2014/2015. Subjek penelitian ini adalah siswa kelas X-3 semester genap SMAN Yosowilangun-Lumajang tahun pelajaran 2014/2015, dengan jumlah siswa 34 yang terdiri dari 8 siswa laki-laki dan 26 siswa perempuan. Penelitian ini menggunakan model Kemmis \& McTaggart. Penelitian ini dirancang dengan dua siklus, tiap siklus terdiri dari 3 kali pertemuan, yakni 2 pertemuan untuk tatap muka dan 1 kali pertemuan untuk ulangan akhir siklus. Jika pada siklus pertama kemampuan metakognisi dan hasil belajar siswa sudah tercapai, maka akan tetap dilanjutkan pada siklus kedua sebagai bahan refleksi untuk mengetahui peningkatan kemampuan metakognisi dan hasil belajar siswa. Penelitian ini menggunakan empat tahapan yaitu perencanaan (planning), tindakan (action), pengamatan (observation), dan refleksi (reflection).

Metode pengumpulan data yang digunakan dalam penelitian menggunakan metode wawancara, observasi, dokumentasi, tes, dan monitoring.

a. Metode Wawancara

Wawancara dilakukan terhadap guru yang dilakukan sebelum dan sesudah penelitian. Wawancara dalam penelitian ini dilakukan kepada guru Biologi SMAN Yosowilangun tahun ajaran 2014/2015. Pertanyaan yang diajukan mengenai kegiatan belajar mengajar, metode, dan model pembelajaran yang digunakan dalam pembelajaran, dan kondisi siswa dalam pross belajar mengajar.

b. Metode Observasi

Observasi dalam penelitian ini adalah pengamatan yang dilakukan secara langsung oleh para observer penelitian untuk mengamati kegiatan pembelajaran. Observasi pada penelitian ini dilakukan untuk melihat sikap (afektif) dan keterampilan (psikomotor) dalam proses belajar mengajar.

c. Metode Dokumentasi

Metode dokumentasi pada penelitian ini digunakan untuk mengumpulkan dokumen-dokumen yang berkaitan denga skripsi berupa nilai ulangan harian, foto, dan video pada saat pembelajaran berlangsung. 


\section{d. Metode Tes}

Metode tes yang digunakan dalam penelitian ini yaitu tes tulis yang dilakukan pada akhir siklus untuk mengetahui peningkatan kemampuan metakognisi dan hasil belajar siswa.

e. Monitoring

Alat yang digunakan untuk mengukur metakognisi siswa menggunakan Metacognitive Awareness Inventory (MAI) Junior yang dikembangkan oleh Schrew dan Dennison, dalam Suratno yang terdiri dari 52 butir soal ${ }^{[4]}$.

Analisis data yang digunakan dalam penelitian ini adalah analisis data kuantitatif. Analisis data dilaksanakan pada hasil kemampuan metakognisi dan hasil belajar siswa (kognitif, afektif, dan psikomotor). Pengolahan data pada penelitian ini menggunakan rumus:

a. Rata-rata kemampuan metakognisi siswa dianalisi menggunakan rumus:
Metacognitive Awareness Inventory (MAI) Junior yang dikerjakan individu setiap akhir siklus. Berikut merupakan peningkatan siswa dari pra siklus ke siklus 1 sampai siklus 2 dengan menggunakan pendekatan keterampilan proses melalui Think Pair Share. Hasil analisis peningkatan kemampuan metakognisi dapat dilihat pada Tabel 1 sebagai berikut.

Tabel 1. Persentase Peningkatan Kemampuan Metakognisi Siswa

\begin{tabular}{ccc}
\hline Siklus & Jumlah Siswa & $\begin{array}{c}\text { Persentase Kemampuan } \\
\text { Metakognisi }\end{array}$ \\
\hline Pra siklus & 34 & $37,48 \%$ \\
\hline Siklus 1 & 34 & $60,98 \%$ \\
\hline Siklus 2 & 34 & $74,31 \%$ \\
\hline Peningkatan dari pra siklus ke siklus 1 & $23,50 \%$ \\
\hline Peningkatan dari siklus 1 ke siklus 2 & $13,33 \%$ \\
\hline Peningkatan dari pra siklus ke siklus 2 & $36,83 \%$ \\
\hline
\end{tabular}

Keterangan: $M \dagger \frac{r}{R}{ }_{2}^{3} 100 \%$

$M=$ rata-rata kemampuan

Berdasarkan Tabel 1. di atas terdapat peningkatan kemampuan metakognisi dari pra siklus ke siklus 1 sampai ke siklus 2 dengan menggunakan pendekatan keterampilan proses melalui think pair share. Tingkat kemampuan metakognisi pada pra siklus sebesar $37,48 \%$, pada siklus 1 mengalami peningkatan menjadi $60,98 \%$, kemudian mengalami peningkatan menjadi 74,31\% pada siklus 2 .

b. Hasil Belajar Siswa

Keterangan:

$$
\text { à } M \grave{T} M_{1} \text { H́ } M_{0}
$$

Hasil belajar yang diukur meliputi aspek kognitif, afektig, $\Delta M=$ peningakatan kemampuan metakognisi dan psikomotor. Aspek kognitif diperoleh dari hasil tes tiap $M_{0}=$ kemampuan metakognisi awal $M_{1}=$ kemampuan metakognisi akhir psikomotor diperoleh pada saat pembelajaran berlangsung b. Persentase hasil belajar (kognitif) dianalisis menggunakan dengan metode observasi yang dibantu oleh observer pada rumus:

Keterangan:

$P=$ persentase hasil belajar siswa

$n=$ skor jawaban siswa

$N=$ skor total

Peningkatan hasil belajar (kognitif) siswa dianalisis menggunakan rumus:

$$
\text { à } P \grave{T} P_{1} \text { H́ } P_{0}
$$

\section{Keterangan:}

$\Delta P=$ peningkatan hasil belajar (kognitif) siswa

$P_{0}=$ hasil belajar (kognitif) awal

$P_{1}=$ hasil belajar (kognitif) akhir

c. Persentase hasil belajar (afektif/ psikomotorik) siswa dianilisis dengan menggunakan rumus:

$$
\text { Hasil belajar } \dagger \frac{\lambda \text { skor yang diperoleh }}{\lambda \text { skormaksimalafektif/psikomotor }}{ }^{3} 100 \%
$$

\section{Hasil Penelitian}

a. Hasil Observasi Kemampuan Metakognisi

Kemampuan metakognisi diukur dengan menggunakan

akhir siklus (siklus 1 dan siklus 2). Aspek afektif dan siklus 1 dan siklus 2. Berikut merupakan peningkatan hasil belajar siswa.

1) Peningkatan Hasil Belajar Kognitif Siswa

Hasil belajar kognitif diambil dari tes yang berbentuk pilihan ganda dan uraian yang dilakukan setiap akhir siklus. Berikut merupakan peningkatan hasil belajar siswa dari aspek kognitif dari pra siklus ke siklus 1 sampai siklus 2 dengan menggunakan pendekatan keterampilan proses melalui Think Pair Share. Hasil analisis peningkatan hasil belajar aspek kognitif dapat dilihat pada Tabel sebagai berikut.

Tabel 2. Persentase peningkatan hasil belajar kognitif siswa

\begin{tabular}{lcccc}
\hline $\begin{array}{c}\text { Tahap } \\
\text { Pembelajaran }\end{array}$ & Nilai & $\begin{array}{c}\text { Jumlah } \\
\text { Siswa } \\
\text { Tuntas }\end{array}$ & $\begin{array}{c}\text { Persentase } \\
(\%)\end{array}$ & $\begin{array}{c}\text { Rata-rata } \\
\text { Kelas }\end{array}$ \\
\hline Pra siklus & $\geq 73$ & 3 & 8,82 & $54,5 \pm 12,95$ \\
\hline Siklus 1 & $\geq 73$ & 11 & 32,35 & $66,06 \pm 14,50$ \\
\hline Siklus 2 & $\geq 73$ & 28 & 82,35 & $77,18 \pm 12,54$ \\
\hline $\begin{array}{l}\text { Peningkatan dari pra siklus ke } \\
\text { siklus 1 }\end{array}$ & 23,53 & 11,56 \\
$\begin{array}{l}\text { Peningkatan dari siklus 1 ke siklus } \\
2\end{array}$ & 50 & 11,12 \\
\end{tabular}



Peningkatan dari pra siklus ke
73,53
22,68

siklus 2

Berdasarkan Tabel 2 di atas terdapat peningkatan hasil belajar siswa pada aspek kognitif dari pra siklus ke siklus 1 sampai siklus 2. Hasil belajar siswa pada pra siklus sebesar $8,82 \%$, pada siklus 1 mengalami peningkatan menjadi $32,35 \%$, kemudian mengalami peningkatan kembali di siklus 2 menjadi $82,35 \%$. Berdasarkan data tersebut dapat dilihat peningkatan hasil belajar kognitif dari pra siklus ke siklus 1 sebesar $23,53 \%$, selanjutnya peningkatan dari siklus $1 \mathrm{ke}$ siklus 2 sebesar $50 \%$, sedangkan peningkatan dari pra siklus ke siklus 2 sebesar 73,53\%.

2) Peningkatan Hasil Belajar Afektif Siswa

Hasil belajar siswa pada aspek afektif diperoleh dari keaktifan siswa selama proses pembelajaran berlangsung dengan metode observasi yang dibantu oleh observer pada siklus 1 dan siklus 2. Metode observasi yang digunakan yaitu dengan menggunakan rubrik lembar observasi yang digunakan sebagai kriteria peningkatan hasil belajar afektif. Berikut merupakan peningkatan hasil belajar siswa pada aspek afektif di setiap siklusnya dengan menggunakan pendekatan keterampilan proses melalui Think Pair Share. Hasil analisis peningkatan hasil belajar aspek afektif dapat dilihat pada Tabel 3 sebagai berikut.

Tabel 3. Persentase peningkatan hasil belajar afektif siswa

\begin{tabular}{lcc}
\hline $\begin{array}{c}\text { Tahap } \\
\text { Pembelajaran }\end{array}$ & Jumlah Siswa & Rata-rata kelas \pm SD \\
\hline Siklus 1 & 36 & $66,24 \pm 6,90$ \\
\hline Siklus 2 & 36 & $78,10 \pm 6,30$ \\
\hline Peningkatan & & 11,86 \\
\hline
\end{tabular}

Berdasarkan Tabel 3 di atas terdapat peningkatan hasil belajar siswa pada aspek afektif disetiap siklusnya. Pada siklus 1, dari 36 siswa rata-rata kelas hasil belajar afektif sebesar 66,24, sedangkan pada siklus 2 mengalami peningkatan menjadi 78,10 . Berdasarkan data tersebut dapat dilihat peningkatan hasil belajar aspek afektif siswa dari siklus 1 ke siklus 2 sebesar 11,86.

\section{3)Peningkatan Hasil Belajar Psikomotor Siswa}

Hasil belajar siswa pada aspek psikomotor diperoleh dari kegiatan siswa selama proses pembelajaran berlangsung dengan metode observasi yang dibantu oleh observer pada siklus 1 dan siklus 2. Metode observasi yang digunakan yaitu dengan menggunakan rubrik lembar observasi yang digunakan sebagai kriteria peningkatan hasil belajar psikomotor Berikut merupakan peningkatan hasil belajar siswa pada aspek psikomotor di setiap siklusnya dengan menggunakan pendekatan keterampilan proses melalui Think Pair Share. Hasil analisis peningkatan hasil belajar aspek psikomotor dapat dilihat pada Tabel 4 sebagai berikut. Tabel 4. Persentase peningkatan hasil belajar psikomotor siswa

\begin{tabular}{ccc}
\hline $\begin{array}{c}\text { Tahap } \\
\text { Pembelajaran }\end{array}$ & Jumlah Siswa & Rata-rata kelas \pm SD \\
\hline Siklus 1 & 36 & $66,10 \pm 8,15$ \\
\hline
\end{tabular}

\begin{tabular}{lcc}
\hline Siklus 2 & 36 & $78,44 \pm 11,26$ \\
\hline Peningkatan & 12,34 \\
\hline
\end{tabular}

Berdasarkan Tabel 4 di atas terdapat peningkatan hasil belajar siswa pada aspek psikomotor disetiap siklusnya. Pada siklus 1, dari 36 siswa rata-rata kelas hasil belajar afektif sebesar 66,10, sedangkan pada siklus 2 mengalami peningkatan menjadi 78,44. Berdasarkan data tersebut dapat dilihat peningkatan hasil belajar aspek afektif siswa dari siklus 1 ke siklus 2 sebesar 12,34.

\section{Pembahasan}

Penelitian ini merupakan penelitian tindakan kelas yang bertujuan untuk meningkatkan kemampuan metakognisi dan hasil belajar siswa melalui penerapan pendekatan keterampilan proses melalui Think Pair Share pada siswa kelas X-3 SMAN Yosowilangun pada materi ekosistem. Penelitian ini dilakukan 2 siklus, tiap siklus terdiri dari 3 kali pertemuan. 2 pertemuan merupakan kegiatan pembelajaran dan 1 pertemuan sebagai tes akhir siklus untuk mengetahui peningkatan kemampuan metakognisi dan hasil belajar siswa. Tahap pelaksanaan yang dilakukan setiap siklus terdiri atas perencanaan, tindakan, observasi, dan refleksi.

Adapun pengetahuan yang diukur dalam metakognisi yaitu deklaratif, prosedural, kondisional, regulasi kognisi, pengaturan infornasi, monitoring, debug (strategi perbaikan), dan evaluasi. Selain kemampuan metakognisi, peneliti juga mengukur hasil belajar siswa yang meliputi aspek kognitif, afektif, dan psikomotor. Aspek kognitif diperoleh dari hasil tes tiap akhir siklus (siklus 1 dan siklus 2), sedangkan untuk aspek afektif dan psikomotor diperoleh pada saat pembelajaran berlangsung dengan metode observasi yang dibantu oleh observer.

Penelitian ini menerapkan pendekatan keterampilan proses melalui Think Pair Share. Penerapan pendekatan keterampilan proses melalui Think Pair Share merujuk dimana siswa dapat bekerja untuk menemukan jawaban dari hasil diskusi bersama kelompoknya dan disertai interaksi dengan lingkungan maupun media yang mengasah keterampilan yang ada dalam diri siswa sehingga tercipta pengetahuan dari hasil pengamatan yang telah dilakukan. Pengetahuan yang diperoleh ini nantinya dapat dijadikan konsep bagi siswa sehingga pengetahuan tersebut dapat menjjadi pengetahuan jangka panjang karena disertai penemuan sendiri. Pembelajaran dengan menggunakan pendekatan keterampilan proses maupun Think Pair Share merupakan pembelajaran baru diterima siswa kelas X-3 SMAN 1 Yosowilangun. Pembelajaran yang biasa dilaksanakan yaitu pembelajaran dengan metode ceramah. Hal tersebut merupakan salah satu hal yang menyebabkan siswa kurang didorong untuk dapat mengasah keterampilan yang ada didirinya dan bepikir secara mandiri.

\section{a. Peningkatan Kemampuan Metakognisi Siswa}

Hal pertama yang diamati dalam penerapan pendekatan proses melalui Think Pair Share adalah kemampuan 
metakognisi siswa. Melalui kemampuan metakognisi ini siswa akan memikirkan cara belajarnya dapat memperoleh informasi secara efektif dan efisien sehingga dapat memperbaiki untuk pembelajaran berikutmya. Berdasarkan hasil observasi awal (pra siklus) menunjukkan bahwa kemampuan metakognisi siswa kelas X IPA 3 SMAN Yosowilangun dikategorikan rendah.

Berdasarkan data yang diperoleh dari hasil observasi menunjukkan bahwa rata-rata kemampuan metakognisi siswa pra siklus adalah 37,48\% dengan kategori beresiko, rata-rata kemampuan metakognisi siswa pada siklus 1 adalah $60,98 \%$ dengan kategori mengembangkan, sedangkan ratarata kemampuan metakognisi siswa pada siklus 2 adalah $74,31 \%$ dengan kategori oke. Berdasarkan data tersebut, terbukti bahwa secara keseluruhan kemampuan metakognisi siswa mengalami peningkatan dari pra siklus ke siklus 1 sebesar 23,50\% dan dari siklus 1 ke siklus 2 sebesar $13,33 \%$. Peningkatan yang terjadi dalam pembelajaran dikarenakan penerapan antara pendekatan keterampilan proses dengan Think Pair Share yang berjalan dengan baik. Hal ini sejalan dengan penelitian Basith juga menunjukkan bahwa pembelajaran Think Pair Share lebih efektif dalam meningkatkan keterampilan metakognisi siswa ${ }^{[5]}$.

Pada tahap Think, setiap siswa berpikir secara mandiri untuk memecahkan suatu permasalahan. Adanya "think time" atau waktu untuk berpikir memberikan kesempatan kepada siswa untuk memikirkan jawaban mereka sendiri, sehingga keterampilan siswa dalam mengontrol dan memonitor belajar mereka sendiri (self regulation) dapat meningkat. Kemampuan siswa dalam mengatur belajarnya sendiri merupakan salah satu indikator bahwa keterampilan metakognitifnya mulai berkembang ${ }^{[6]}$.

Pada tahap Pair, siswa berpasangan dengan siswa lain untuk mendiskusikan apa yang telah dipikirkannya pada tahap think. Hasil dikusi selama tahap pair dapat menambah informasi bagi masing-masing siswa, sehingga hasil akhir yang didapat akan lebih baik dari jawaban mereka sebelumnya. Masing-masing siswa berkesempatan untuk saling memonitor dan mengevaluasi hasil pemikirannya sendiri dan hasil pemikiran siswa yang menjadi pasangannya. Selain itu dalam tahap ini juga disisipkan pendekatan keterampilam proses, dimana siswa tidak hanya pasif mendapatkan informasi dari guru, melainkan mengasah keterampilan-keterampilan dasar pada dirinya melalui pengalaman langsung. Gabungan antara tahap Pair dan pendekatan keterampilan proses menjadikan siswa tidak hanya dapat bertukar ide atau pendapat dengan siswa lain, melainkan juga membangun suatu konsep baru melalui pengalaman langsung. Siswa yang belajar dalam kelompokkelompok kecil memiliki kecenderungan untuk mengasah keterampilan metakognisi daripada siswa yang belajar dengan cara mendengarkan ceramah dari guru ${ }^{[7]}$.

Pada tahap share (berbagi) guru meminta pada pasangan untuk berbagi hasil pemikiran mereka dengan seluruh kelas. Melalui tahap ini, semua kelompok dimungkinkan untuk saling mengevaluasi hasil pemikiran mereka sehingga setiap siswa memiliki kesempatan untuk mengevaluasi aktivitas kognitif baik dirinya sendiri maupun teman sekelasnya. Selain itu, siswa akan mendapat tambahan informasi dan menjadi lebih paham bagaimana cara memecahkan masalah yang diberikan oleh guru.

Keterampilan metakognisi siswa sangat diperlukan dalam proses pembelajaran yang sedang sedang berlangsung, karena menentukan kemampuan kognisi siswa. Peneliti lain yang juga sependapat ialah Imel yang menyatakan bahwa keterampilan metakognisi diperlukan untuk kesuksesan belajar, mengingat keterampilan metakognisi memungkinkan siswa mampu mengelola kecakapan kognitif dan mampu melihat kelemahannya sehingga dapat dilakukan perbaikan pada tindakan-tindakan berikutnya ${ }^{[8]}$. Apabila siswa menggunakan keterampilan metakognisinya dengan baik maka hasil belajar yang diperoleh juga akan ikut lebih baik, karena siswa ini melakukan perencanaan, perkembangan, serta evaluasi terhadap proses pembelajaran yang dilaksanakan.

b. Peningkatan Hasil Belajar Siswa

Hasil belajar siswa yang diukur dalam penelitian ini ada tiga aspek, yakni aspek kognitif, afektif dan psikomotor. Peningkatan hasil belajar aspek kognitif dapat diketahui melalui analisis data dari hasil tes atau ulangan harian siswa di setiap akhir siklus.

Prestasi belajar siswa yang memiliki tingkat metakognisi tinggi akan lebih baik jika dibandingkan dengan siswa yang metakognisi rendah. Jadi siswa yang memiliki metakognisi lebih tinggi akan searah dengan prestas belajar yang lebih baik. Hal tersebut sesuai dengan penelitian yang dilakukan peneliti. Berdasarkan data yang diperoleh pada siklus 1 menunjukkan bahwa terdapat peningkatan hasil belajar siswa dengan penerapan pendekatan keterampilan proses melalui Think Pair Share, yaitu dari ketuntasan 8,82\% menjadi $32,35 \%$ dengan peningkatan $23,53 \%$, akan tetapi untuk ketuntasan hasil belajar tersebut belum mencapai target yaitu ketuntasan klasikal yang telah ditetapkan di SMAN Yosowilangun yakni $\geq 80 \%$ dari seluruh siswa yang mendapat nilai $\geq 73$, sehingga perlu adanya tindakan perbaikan agar dapat menyelesaikan permasalahan di kelas X-3 SMAN Yosowilangun. Faktor yang menyebabkan masih belum mencapai ketuntasan hasil belajar aspek kognitif tersebut salah satunya adalah siswa masih cukup kebingungan atau belum terbiasa dengan penerapan langkahlangkah keterampilan proses melalui Think Pair Share.

Berdasarkan analisis data hasil ulangan harian siklus 2 yang dilakukan pada siswa kelas X IPA 3, menunjukkan bahwa persentase ketuntasan hasil belajar siswa aspek kognitif adalah $82,35 \%$. Terjadi peningkatan sebanyak $50 \%$ dari siklus 1 dengan persentase $32,35 \%$ meningkat menjadi $82,35 \%$ pada siklus 2, sehingga peningkatan hasil belajar siswa dari pra siklus ke siklus 2 sebesar 73,53\%. Peningkatan yang terjadi dari siklus ke siklus dikarenakan pada model Think Pair Share sendiri memberikan banyak waktu bagi siswa untuk berfikir dan pola berdiskusi dengan pasangannya sehingga anak akan membangun sendiri skema pengetahuan serta membangun konsep-konsep melalui diskusi sehingga siswa akan lebih memahami konsep materi 
yang dipelajari. Hal ini sependapat dengan Amstrong dan Savage yang menyatakan bahwa keuntungan Think Pair Share dapat membantu siswa belajar untuk berbagi ide-ide mereka dengan pasangannya ${ }^{[9]}$. Siswa akan lebih mudah belajar dikarenakan terdapat dua ide yang digabungkan. Selain itu Think Pair Share juga membantu siswa untuk memahami pentingnya mengintegrasi ide pribadi dengan pasangannya sehingga akan dapat dibangun konsep melalui penggabungan ide tersebut. Hal ini sama dengan penelitian sebelumnya yang telah dilakukan oleh Rusmaryanti, bahwa model pembelajaran kooperatif Think Pair Share dapat meningkatkan hasil belajar biologi pada siswa kelas VIII A MTs Al Huda 2 Jenawi Karanganyar tahun pelajaran $2012 / 2013^{[10]}$.

Berdasarkan analisis data hasil belajar aspek psikomotorik menunjukkan secara klasikal siswa yang semakin meningkat, hal ini ditunjukkan dengan rata-rata 66,10 pada siklus 1 dan meningkat menjadi 78,44 pada siklus 2 . Peningkatan dari siklus 1 ke siklus 2 sebesar 12,34. Peningkatan hasil belajar aspek psikomotor terjadi dikarenakan dalam penelitian juga menerapkan keterampilan proses. Penerapan pendekatan keterampilan proses menyebabkan siswa tidak pasif menerima dan menghafal informasi yang diberikan guru, tetapi berusaha menemukan konsep melalui pengalaman langsung. Hal ini sependapat dengan Sagala yang menyatakan bahwa keterampilan proses adalah/ suatu pendekatan pengajaran yang memberi kesempatan kepada siswa untuk ikut menghayati proses penemuan atau penyusunan suatu konsep ${ }^{[11]}$. Keterampilan proses menjadikan siswa dapat mengasah pola berpikirnya sehingga dapat meningkatkan kualitas hasil belajar. Sesuai dengan penelitian yang dilakukan oleh Harlen, yaitu penggunaan keterampilan proses sangat penting untuk mengukur, menyimpulkan, dan memonitoring tujuan pembelajaran ${ }^{[12]}$.

Hasil belajar afektif siswa juga mengalami peningkatan yakni berdasarkan analisis hasil belajar aspek afektif secara klasikal juga menunjukkan adanya peningkatan hasil belajar selama siklus 1 dan siklus 2. Rata-rata hasil belajar aspek afektif pada siklus 1 sebesar 66,24 dan pada siklus 2 sebesar 78,10 . Peningkatan hasil belajar aspek afektif secara klasikal sebesar 11,77 walaupun terjadi peningkatan yang tidak begitu besar, namun disetiap pertemuan terdapat perubahan ke arah yang lebih baik. Peningkatan hasil belajar aspek afektif ini terjadi karena adanya penerapan pendekatan keterampilan proses melalui Think Pair Share dengan baik sehingga tercipta suatu pembelajaran yang menunjang hasil belajar dari aspek kognitif dan psikomotor. Hal tersebut secara tidak langsung akan mempengaruh hasil belajar dari aspek afektif juga mengalami peningkatan.

\section{Kesimpulan dan Saran}

Berdasarkan hasil dan pembahasan yang telah diuraikan dapat diambil kesimpulan sebagai berikut.

1) Penerapan pendekatan keterampilan proses melalui Think Pair Share dapat meningkatkan kemampuan metakognisi siswa kelas X IPA 3 SMAN Yosowilangun pada materi Ekosistem, yaitu pada pada pra siklus memiliki rata-rata persentase aktivitas belajar siswa klasikal 35,80\% dengan kriteria rendah, pada siklus 1 memiliki rata-rata persentase klasikal $60,69 \%$ dengan kriteria sedang dan pada siklus 2 memiliki rata-rata persentase klasikal $74,38 \%$ dengan kriteria tinggi. Peningkatan rata-rata persentase dari pra siklus ke siklus 1 sebesar $24,89 \%$, dan dari siklus 1 ke siklus 2 sebesar 13,69\%. Peningkatan kemampuan metakognisi dari pra siklus ke siklus 2 sebesar 38,58\%.

2) Penerapan pendekatan keterampilan proses melalui Think Pair Share dapat meningkatkan hasil belajar siswa pada aspek kognitif secara klasikal, yaitu pada pra siklus memiliki rata-rata kelas sebesar 54,5. siklus 1 memiliki rata-rata kelas sebesar 66,06 dan siklus 2 memiliki rata-rata kelas sebesar 7,18. Peningkatan hasil belajar siswa rata-rata kelas dari pra siklus ke siklus 2 sebesar 22,68. Rata-rata hasil belajar aspek afektif secara klasikal pada siklus 1 sebanyak 66,24 dan meningkat pada siklus 2 menjadi 78,10. Kemudian, pada hasil belajar aspek psikomotorik menunjukkan rata-rata kelas secara klasikal siswa yang semakin meningkat dengan persentase 66,10 pada siklus 1 dan meningkat menjadi 78,44 pada siklus 2 .

Saran dalam penelitian ini adalah sebagai berikut: guru hendaknya selalu melakukan inovasi dalam pembelajaran untuk meningkatkan aktivitas dan hasil belajar siswa. Pendekatan keterampilan proses melalui Think Pair Share ini dapat dijadikan sebagai inovasi pembelajaran yang dapat digunakan. Pendekatan keterampilan proses melalui Think Pair Share dalam penerapannya membutuhkan waktu yang banyak sehingga guru harus mengatur waktu seefektif mungkin agar pembelajaran dapat berjalan secara maksimal. Saat penerapan pendekatan keterampilan proses melalui Think Pair Share hendaknya guru selalu membimbing dan memberi semangat kepada siswa karena pelaksanaan pembelajaran ini melatih rasa percaya diri kepada siswa terutama dalam hal mengembangkan keterampilan dasar dan diskusi. Bagi peneliti lain, dalam penerapan pendekatan keterampilan proses melalui Think Pair Share dapat ditambahkan variabel yang diteliti yaitu retensi siswa.

\section{Ucapan Terima Kasih}

Paper disusun untuk memenuhi syarat memperoleh gelar sarjana (S1) pada Program Studi Pendidikan Biologi, Universitas Jember. Penulis mengucapkan terima kasih kepada Program Studi Pendidikan Biologi, Jurusan Pendidikan MIPA, Fakultas Keguruan dan Ilmu Pendidikan Uneversitas Jember sebagai tempat menimba ilmu kurang lebih selama 4 tahun ini. Terima kasih kepada Kepala Sekolah dan Guru mata pelajaran Biologi SMAN 1 Yosowilangun Lumajang yang telah memberikan izin kepada penulis untuk melakukan penelitian di SMAN 1 Yosowilangun Lumajang.

\section{Daftar Pustaka}

[1] Sudjana, N. 2004. Dasar-dasar Proses Belajar Mengajar. Bandung: Sinar Baru Algensido.

[2] Coutinho, S. A. 2007. The Relationship Between Goals Metacognition and Academic Success. [serial on line]. http://www.academicjournals.org. [31 Maret 2016] 
[3] Arends, Richard I. 2008. Learning to Teach. Yogyakarta: Pustaka Belajar.

[4] Suratno. 2008a. Pengaruh Strategi Kooperatif Jigsaw dan Reciprocal Teaching Terhadap Keterampilan Metakognisi dan Hasil Belajar Kognitif Siswa SMA Berkemampuan Atas dan Bawah di Jember. Proposal disertasi. Malang: Program Studi Pendidikan Pasca Sarjana Universitas Negeri Malang.

[5] Basith, A. 2011. Hubungan Keterampilan Metakognitif dan Hasil Belajar Matapelajaran IPA pada Siswa Kelas IV SD dengan Strategi Pembelajaran Jigsaw dan Think Pair Share (TPS). Skripsi tidak diterbitkan. Malang: Jurusan Biologi FMIPA UM.

[6] Livingston, J. 1997. Metacognition. [serial online]. http://www.gse.buffalo.edu/fas/shuell.cep564/Metacog.htm. $\quad[28$ Maret 2016].

[7] Downing, K. Kwong, T., Chan, S. W., Lam, T.F., dan Downing, W. K. 2009. Problem-Based Learning and the Development of Metacognition. High Education, 57(5).

[8] Imel, Susan. 2000. Metacognitive Skills for Adult Learning. [Online]. http://www.ericacve.org/pubs.asp. [29 April 2016].

[9] Savage dan Amstrong, 1996. Effective Teaching in Elementary Social Studies. Amerika: United of Amerika.

[10] Rusmaryanti, D. 2013. Meningkatkan Hasil Belajar Biologi dengan Model Pembelajaran Kooperatif TPS (Think Pair Share) pada Siswa kelas VIIIA MTs Al Huda 2 Jenawi Karanganyar Tahun Pelajaran 2012/2013. Jurnal Pendidikan, 22 (3).

[11] Sagala, S. 2010. Konsep dan Makna Pembelajaran. Bandung: Alfabeta.

[12] Harlen, Wynne. 1999. Purposes and Procedures for Assessing Science Process Skills. Education Journals, 6 (1).

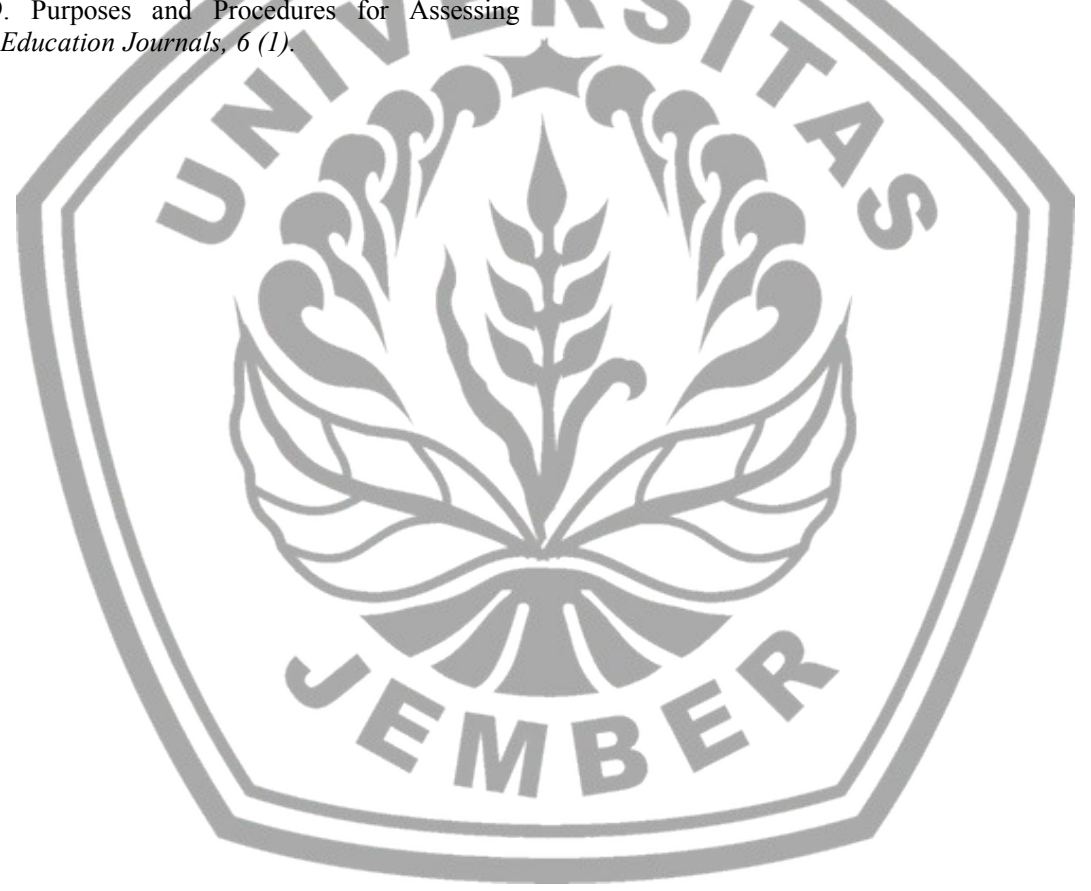

